\title{
Is It Possible to Intervene in the Capacity of Trypanosoma cruzi to Elicit and Evade the Complement System?
}

\section{OPEN ACCESS \\ Edited by: \\ Wanderley De Souza, \\ Federal University of Rio de \\ Janeiro, Brazil \\ Reviewed by: \\ Marisa Mariel Fernandez, \\ Institute of Studies on Humoral \\ Immunity (IDEHU), Argentina \\ Walderez Ornelas Dutra, \\ Federal University of Minas \\ Gerais, Brazil \\ ${ }^{*}$ Correspondence: \\ Arturo Ferreira \\ aferreir@med.uchile.cl \\ Galia Ramírez-Toloza \\ galiaram@uchile.cl \\ Viviana P. Ferreira \\ viviana.ferreira@utoledo.edu}

Specialty section:

This article was submitted to

Microbial Immunology,

a section of the journal

Frontiers in Immunology

Received: 04 October 2021 Accepted: 19 November 2021 Published: 16 December 2021

Citation:

Ramírez-Toloza G,

Aguilar-Guzmán L, Valck C,

Menon SS, Ferreira VP and

Ferreira A (2021) Is It Possible

to Intervene in the Capacity of

Trypanosoma cruzi to Elicit and Evade the Complement System?

Front. Immunol. 12:789145. doi: 10.3389/fimmu.2021.789145

\author{
Galia Ramírez-Toloza ${ }^{1 *}$, Lorena Aguilar-Guzmán ${ }^{2}$, Carolina Valck ${ }^{3}$, Smrithi S. Menon ${ }^{4}$, \\ Viviana P. Ferreira ${ }^{4 *}$ and Arturo Ferreira ${ }^{3 *}$ \\ ${ }^{1}$ Department of Preventive Veterinary Medicine, Faculty of Veterinary Medicine and Livestock Sciences, University of Chile, \\ Santiago, Chile, ${ }^{2}$ Department of Pathology, Faculty of Veterinary Medicine and Livestock Sciences, University of Chile, \\ Santiago, Chile, ${ }^{3}$ Department of Immunology, Institute of Biomedical Sciences (ICBM), Faculty of Medicine, University of \\ Chile, Santiago, Chile, ${ }^{4}$ Department of Medical Microbiology and Immunology, College of Medicine and Life Sciences, \\ University of Toledo, Toledo, $\mathrm{OH}$, United States
}

Chagas' disease is a zoonotic parasitic ailment now affecting more than 6 million people, mainly in Latin America. Its agent, the protozoan Trypanosoma cruzi, is primarily transmitted by endemic hematophagous triatomine insects. Transplacental transmission is also important and a main source for the emerging global expansion of this disease. In the host, the parasite undergoes intra (amastigotes) and extracellular infective (trypomastigotes) stages, both eliciting complex immune responses that, in about $70 \%$ of the cases, culminate in permanent immunity, concomitant with the asymptomatic presence of the parasite. The remaining $30 \%$ of those infected individuals will develop a syndrome, with variable pathological effects on the circulatory, nervous, and digestive systems. Herein, we review an important number of $T$. cruzi molecules, mainly located on its surface, that have been characterized as immunogenic and protective in various experimental setups. We also discuss a variety of parasite strategies to evade the complement system - mediated immune responses. Within this context, we also discuss the capacity of the T. cruzi infective trypomastigote to translocate the ERresident chaperone calreticulin to its surface as a key evasive strategy. Herein, it is described that $T$. cruzi calreticulin inhibits the initial stages of activation of the host complement system, with obvious benefits for the parasite. Finally, we speculate on the possibility to experimentally intervene in the interaction of calreticulin and other T. cruzi molecules that interact with the complement system; thus resulting in significant inhibition of $T$. cruzi infectivity.

Keywords: Trypanosoma cruzi, host-parasite interaction, complement system, complement regulatory proteins, host-immune evasion 


\section{INTRODUCTION}

Chagas disease, or American trypanosomiasis, is a multisystemic disorder that affects the cardiovascular, digestive, and central nervous systems (1). Chagas disease is one of the 20 most "neglected tropical diseases", as defined by The World Health Organization (WHO) (2). About 6-7 million people are infected worldwide, with almost 100 million at risk, indicating that this disease is a serious public health issue $(3,4)$. In endemic countries, Chagas disease is primarily transmitted by triatomine vectors, predominantly in rural areas. However, human migration and other forms of transmission have changed the epidemiology/ epizootiology of Chagas disease, which is currently affecting peri-urban and urban areas $(5,6)$. Other important mechanisms of transmission include blood transfusion, organ transplants, oral ingestion, laboratory accidents, vertical transmission from mother to child, or needle sharing $(2,7)$.

Chagas disease is caused by Trypanosoma cruzi (T. cruzi), a hemoflagellate parasite transmitted through various species of hematophagous reduviid insects ('kissing bugs') mainly in endemic areas such as Latin America (8). Trypomastigotes, the infective form, circulate in the blood of mammals and infect nucleated cells, where they transform into amastigotes, the replicative form. T. cruzi needs to evade the host immune system, especially during the acute phase of the infection, and various mechanisms have been described for the parasite to control the innate and adaptive host immune responses. In the regulation of adaptive immune responses, inhibition of polyclonal activation of $\mathrm{B}$ and $\mathrm{T}$ cells may be relevant in infected people (9) and in mice $(10,11)$. Additionally, a decrease in the proliferative response of lymphocytes, as well as in the production of interleukin-2 (IL-2) in chronic Chagas disease patients has also been reported (12). Moreover, the parasites induce immunomodulatory molecules, such as IL-10 and transforming growth factor- $\beta$ (TGF- $\beta$ ), which lead to failure in the maturation of antigen-presenting cells and poor antigenic presentation (12).

To evade the innate immune response, one of the most important mechanisms adopted by T. cruzi is to modulate complement system (C) activity (Figure 1). Thus, infective trypomastigotes, are resistant to $\mathrm{C}$, while non-infective epimastigotes, present in the reduviid insect vector, are extremely sensitive $(13,14)$. However, this $\mathrm{C}$ resistance varies among T. cruzi strains (15), being mediated by (a) surface expression of molecules such as glycoprotein 58/68 (gp 58/68) (16), T. cruzi complement regulatory protein (TcCRP) (17-19), T. cruzi trypomastigote-decay accelerating factor (T-DAF) (20, 21), T. cruzi calreticulin (TcCalr) (22), C2 receptor inhibitor trispanning (CRIT) (Table 1) and/or (b) secretion or acquisition of molecules from host blood stream, such as Factor H (FH) (36), and T. cruzi induced host extracellular vesicles (EV) (37). These molecules inhibit $\mathrm{C}$ at the initial steps of the cascade or inhibit $\mathrm{C} 3$ and/or C5 convertases of the classical (CP), lectin (LP) and/or alternative (AP) pathways (37) (Figure 1). However, studies on their therapeutic or prophylactic values are still limited. Herein, we will focus on the interactions of these molecules with $\mathrm{C}$, and in their potential therapeutic/prophylactic roles.

\section{T. CRUZI MOLECULES INHIBITING C AT THE INITIAL STEPS}

T. cruzi complement $\mathrm{C} 2$ receptor inhibitor trispanning protein (CRIT), a $32 \mathrm{kDa}$ protein containing a 27 amino acid extracellular domain (38-40), is a C2 receptor, present on $T$. cruzi, that inhibits $\mathrm{C} 2$ cleavage by C1s (38). First described in the $\mathrm{Y}$ strain, CRIT expressed on trypomastigotes binds to, and inactivates $\mathrm{C} 2$, inhibiting the $\mathrm{CP}$ and $\mathrm{LP}$ (23). The same group then showed that in the LP, the extracellular domain 1 of CRIT inhibits MBL-Associated Serine Protease-2 (MASP-2) mediated C2 cleavage, thus impairing formation of the C3 convertase (24). Thus, parasites overexpressing CRIT are highly resistant to Cmediated lysis (24). CRIT is expressed in different T. cruzi strains and clones, such as CL Brenner, Colombiana and Dm28c, with high sequence identity ( $88-98 \%)$ (23), but apparently its gene is only functional in some T. cruzi lineages. A recent study evaluating the resistance of $\mathrm{C}$ in different TcI strains with high (Qro) and low (Ninoa) virulence, demonstrated that the mRNA of CRIT is three - fold lower in the low virulence strain (41).

T. cruzi calreticulin (TcCalr) (formerly known as TcCRT), is a highly pleiotropic protein, with inhibitory effects in $\mathrm{C}$ activation and infectivity. In addition to these roles, TcCalr, also reduces angiogenesis and tumor growth, however, these roles have been described and reviewed elsewhere $(25,42-46)$. Infective trypomastigotes carrying a monoallelic deletion of the TcCalr gene, are significantly susceptible to C-mediated lysis. On the contrary, parasites overexpressing TcCalr are significantly more resistant to $\mathrm{CP}$ and LP-mediated lysis $(26,47)$. TcCalr binds to the collagenous tails of $\mathrm{Clq}$, inhibiting the $\mathrm{CP}$ (22). Its central TcCalr S-domain (aa 159-281) competes with the (C1r-C1s) tetrameric complex to bind $\mathrm{Clq}$, thus decreasing $\mathrm{C} 4 \mathrm{~b}$ generation and in turn decreasing the levels of the generated CP C3 and C5 convertases (22). Furthermore, both CP serine-proteases, C1s and $\mathrm{C} 1 \mathrm{r}$, bind TcCalr in vitro, but TcCalr does not inhibit the C4-activating function of solid phase-bound C1s. Perhaps, C1s inactivation occurs only when the serine protease is part of $\mathrm{C} 1$ complex (C1q, (C1r, C1s) 2 ) (27). Additionally, TcCalr competes with the capacity of the serine proteases to bind $\mathrm{C} 1 \mathrm{q}$, but does not displace them from the preformed $\mathrm{C} 1$ complex (27). In Chagas disease, this role may be also important in other steps of the parasite cycle, since Triatoma infestans calreticulin (TiCalr), present in the insect's saliva, also binds $\mathrm{C} 1$, inhibiting the $\mathrm{CP}$. Perhaps, TiCalr prevents mammal C-mediated damage to the vector's digestive mucosa (48). TcCalr and its S-domain (aa 159281) also binds mannan-binding lectin (MBL) and Ficolins, inhibiting the LP $(22,28)$. Although TcCalr binds to the collagenous tails of MBL and reduces the binding of MBL to mannose, it does not inhibit C4 activation (22). On the other hand, L-Ficolin (but not H-Ficolin) binds to TcCalr, interfering with its activation via Lipoteichoic-acid. Moreover, because trypomastigotes translocate significantly higher amounts of TcCalr to their surfaces, L-Ficolin binds preferentially to this infectious stage of the parasite (28). Thus, TcCalr inhibits both CP and LP $(22,27,28)$.

TcCalr is an ER-resident protein that translocates to the parasite external microenvironment. Although TcCalr is located 


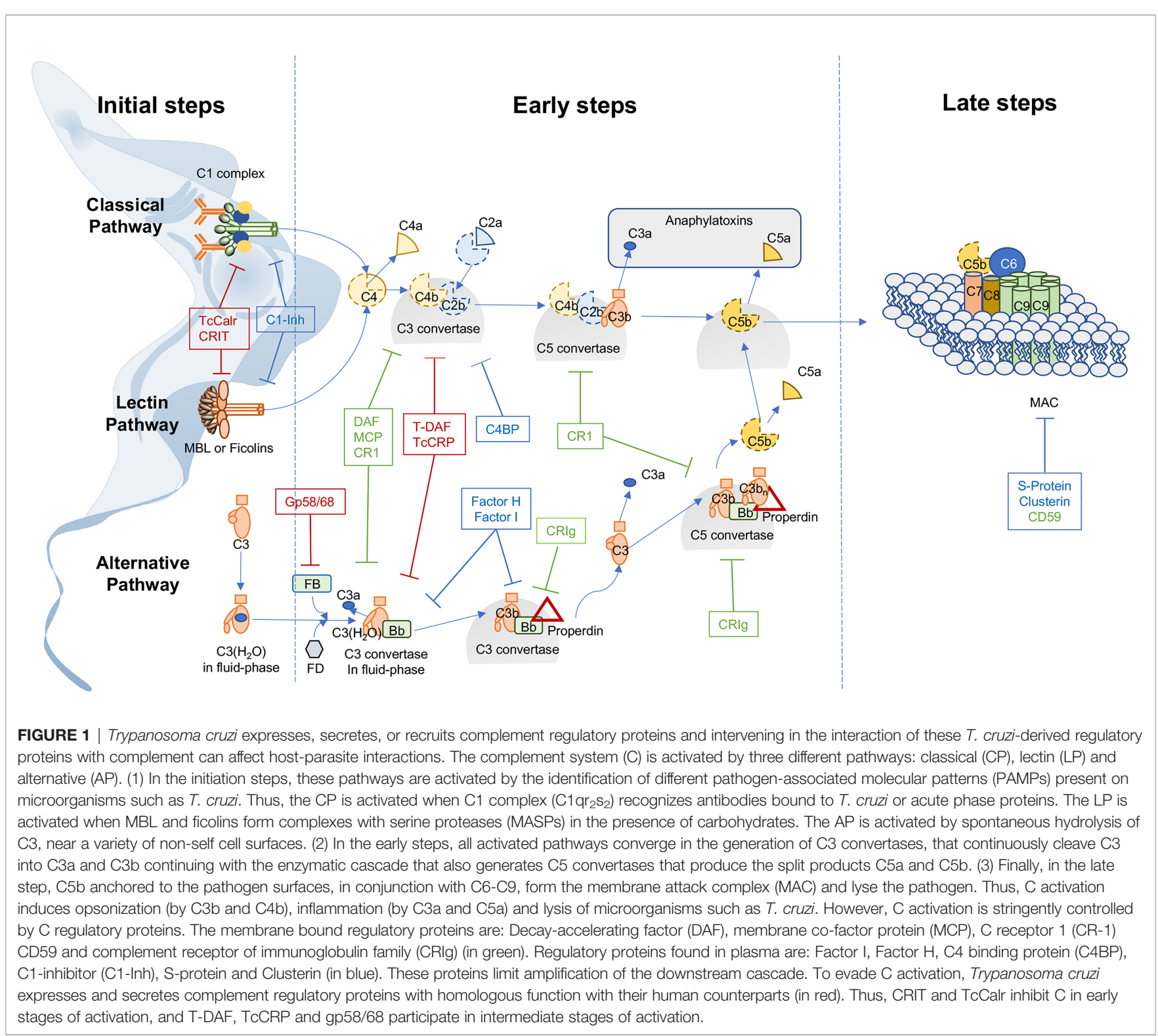

mainly in the ER, it is also found in the Golgi, reservosomes, flagellar pocket, cell surface, cytosol, nucleus and kinetoplast (22, 49, 50). Thus, C1q and TcCalr colocalize on the parasite surface, mainly on the area of flagellar emergence (16). It is well known that CALR (the human TcCalr counterpart), participates as an "eat me" signal in apoptotic cancer cells, promoting their phagocytosis (51). This process is mediated by the CALR/C1q interaction on the apoptotic cells, which is recognized, in turn, by a C1q receptor (also identified as membrane bound CALR) on the phagocytic cell (52). Therefore, the TcCalr - C1q interaction underlies a molecular mimicry strategy to enhance parasite internalization. In agreement with these findings, tissue-culture trypomastigotes bind $\mathrm{C} 1 \mathrm{q}$, increasing internalization into monocytes and macrophages (51). However, recombinant TcCalr (rTcCalr) and DNA-based immunization induces specific antibody production and promotes higher parasitemias in mice (29). This apparent paradox is resolved when anti-TcCalr $\mathrm{F}\left(\mathrm{ab}^{\prime}\right)_{2}$ antibodies are used to inhibit the TcCalr/Clq interaction in vivo, demonstrating that $\mathrm{Fc}$-antibody regions recruit $\mathrm{Clq}$ thus promoting higher infectivity $(29,53)$. Unlike the infective forms, epimastigotes are highly sensitive to $\mathrm{C}$ activation, most likely due, at least in part, to the marginal levels of TcCalr expressed on their surfaces $(22,44)$. However, when TcCalr is exogenously added to non-infective epimastigotes, the parasites are internalized by fibroblasts in a C1q-dependent manner (54). Additionally, mice inoculated with genetically modified trypomastigotes, underexpressing TcCalr, did not generate detectable parasitemia nor anti-T. cruzi IgG antibodies. Accordingly, parasites underexpressing TcCalr showed a reduced capacity to evade the $\mathrm{C}$ and to infect cells (26).

TcCalr-C1q interaction is also relevant in human placenta which expresses high CALR levels (55-57). In an ex vivo model, 
TABLE 1 | Complement regulatory proteins expressed and/or secreted by Trypanosoma cruzi, their roles in the host-parasite interaction and as potential therapeutic or prophylactic tools.

\begin{tabular}{|c|c|c|c|c|}
\hline $\begin{array}{l}\text { Complement } \\
\text { regulatory protein }\end{array}$ & Functions in Complement system evasion & $\begin{array}{l}\text { Other roles in the host-parasite } \\
\text { interaction }\end{array}$ & $\begin{array}{l}\text { Therapeutic or prophylactic } \\
\text { potential }\end{array}$ & Reference \\
\hline $\begin{array}{l}\text { Trypanosoma cruzi } \\
\text { Complement C2 } \\
\text { Receptor Inhibitor } \\
\text { Trispanning Protein } \\
\text { (CRIT) }\end{array}$ & $\begin{array}{l}\text { CRIT is a } 32 \mathrm{kDa} \text { protein that inhibits the } \mathrm{C} 2 \\
\text { cleavage by } \mathrm{C} 1 \mathrm{~s} \text { and MASP2 and impairs } \mathrm{C} 3 \\
\text { convertase formation in } \mathrm{CP} \text { and } \mathrm{LP} \text {. }\end{array}$ & Undetermined & Undetermined & $(23,24)$ \\
\hline $\begin{array}{l}\text { Trypanosoma cruzi } \\
\text { calreticulin (TcCalr) }\end{array}$ & $\begin{array}{l}\text { TcCalr is a } 45 \mathrm{kDa} \text { protein expressed on the parasite } \\
\text { surface and secreted that inhibits the } \mathrm{CP} \text { and } \mathrm{LP} \text { in } \\
\text { initial step of activation. TcCalr binds to } \mathrm{C1}, \mathrm{MBL} \\
\text { and L-Ficolin. }\end{array}$ & $\begin{array}{l}\text { TcCalr is highly immunogenic in } \\
\text { humans and mice and binds C1q, } \\
\text { promoting infectivity. Additionally, } \\
\text { TcCalr inhibits angiogenesis and } \\
\text { tumor growth. }\end{array}$ & $\begin{array}{l}\text { Recombinant TcCalr and DNA-based } \\
\text { immunization promote higher } \\
\text { parasitemias. Anti - TcCalr F(ab') }{ }_{2} \\
\text { antibody fragments reduce parasitemia } \\
\text { and increase survival in mice. }\end{array}$ & $\begin{array}{c}(22, \\
25-29)\end{array}$ \\
\hline $\begin{array}{l}\text { Trypomastigote } \\
\text { Decay-Accelerating } \\
\text { Factor (T-DAF) }\end{array}$ & $\begin{array}{l}\text { T-DAF is an } 87-93 \mathrm{kDa} \text { glycoprotein expressed on } \\
\text { the parasite surface that interferes with assembly of } \\
\text { the C3 and C5 convertase of both CP, LP (probably) } \\
\text { and AP. }\end{array}$ & $\begin{array}{l}\text { Highly immunogenic in humans } \\
\text { and mice. }\end{array}$ & $\begin{array}{l}\text { Recombinant T-DAF immunization } \\
\text { promotes antibody production in } \\
\text { different animal species, leading to } \\
\text { parasite lysis in vitro. }\end{array}$ & $\begin{array}{l}(20,21, \\
30)\end{array}$ \\
\hline $\begin{array}{l}\text { Glycoprotein 58/68 } \\
\text { (Gp58/68) }\end{array}$ & $\begin{array}{l}\text { Gp58/68 is a } 58-68 \mathrm{kDa} \text { protein expressed on the } \\
\text { parasite surface that interferes with the C3 } \\
\text { convertase formation by binding Factor B, thus } \\
\text { specifically inhibiting the AP. }\end{array}$ & $\begin{array}{l}\text { Gp58/68, first described as a } \\
\text { receptor to fibronectin, has a likely } \\
\text { role in infectivity. }\end{array}$ & Undetermined & $(16,35)$ \\
\hline
\end{tabular}

CP, Classical pathway; LP, Lectin pathway; AP, Alternative pathway; C, Complement system.

TcCalr is shown to bind $\mathrm{Clq}(58)$ and possibly recognized by $\mathrm{cClqR}$ (a membrane-bound CARL form) present on the placental syncytiotrophoblast. This interaction is also inhibited by polyclonal $\mathrm{F}(\mathrm{ab})_{2}$ anti-TcCalr antibodies, a fact reflected in lower parasite infectivity in an ex vivo experimental model. An in vivo infectivity inhibitory capacity for anti-TcCalr antibody fragments can be envisaged, considering that, in humans, congenital transmission ranges from $2 \%$ to $13.8 \%$ in different studies (59).

As mentioned, TcCalr also binds to MBL and L-Ficolin (22, 27). However, the potential role of TcCalr-MBL or TcCalrFicolin interactions, in the infectivity process, requires additional research. One study comparing two T. cruzi strains, susceptible and resistant to $\mathrm{C}$, suggested that $\mathrm{MBL}$ also participates in the infectivity process while the parasite deactivates the LP (60). Nevertheless, the complete inactivation of the LP does not confer higher susceptibility to the infection since, mice deficient in MASP-2 show similar parasitemia and survival compared to wild-type (61). This fact may indicate that the LP is not essential to control parasitemia and infectivity. However, low levels of L-Ficolin and FCN2 (gene codifying for LFicolin) polymorphism are associated with chronic Chagas disease (62).

Based on in silico structural TcCalr models, an interesting peptide (VC-TcCalr), at the TcCalr $\mathrm{N}$-domain, has been delimited and chemically synthesized. VC-TcCalr is a strong dipole, spatially stable (more than its CALR counterpart), that interacts with collagen-like tails and scavenger receptors. This peptide binds to $\mathrm{Clq}$ and was anti-angiogenic in a Gallus gallus chorioallantoic membrane assays (63). This crystallographic structural study defines CALR conformational rearrangements that could be informative in future therapeutic investigations of parasite CALR (64), mainly in its anti-complement and antineoplastic effects.

\section{T. CRUZI MOLECULES THAT INHIBIT C3 AND C5 CONVERTASES}

Metacyclic, bloodstream and tissue culture-derived T. cruzi trypomastigotes express an $87-93 \mathrm{kDa}$ glycoprotein (T-DAF), with decay accelerating activity on the $\mathrm{CP}$ and $\mathrm{AP}$ C3 and C5 convertases $(20,21)$. This activity was previously found in human decay-accelerating factor (DAF), a $70 \mathrm{kDa}$ glycophospholipidanchored membrane protein. DAF is present on erythrocytes, neutrophils, lymphocytes, monocytes, platelets, and endothelial cells (65). T-DAF is functionally, but not structurally analogous to human DAF (21). T-DAF mRNA levels are lower in C-susceptible T. cruzi strains (41). A partial T-DAF cDNA clone and its deduced protein sequence showed $40 \%$ homology with a portion of the coding region for DAF (21). T-DAF is immunogenic in experimental animals, inducing antibodies with parasitic lysis capacity (21). Additionally, antibodies against T-DAF were identified in patients chronically infected with T. cruzi (21, 66, 67 ); thus, T-DAF is highly immunogenic in both humans and mice, suggesting a serodiagnosis value (30).

T. cruzi C regulatory protein (TcCRP), also named gp160, is a $160 \mathrm{kDa}$ GPI-anchored glycoprotein (17) that can be spontaneously released by the trypomastigotes. This protein can inhibit both the CP and AP and stable TcCRP-transfected 
epimastigotes were found to be protected from C-mediated lysis (31). There are multiple copies of TcCRPs in the T. cruzi genome, highlighting the importance of this protein for T. cruzi. The encoded proteins are not only structurally and functionally similar to DAF $(17,18,31)$, but are also similar to members of the T. cruzi-Trans-Sialidase (TS) superfamily (68). Proteins from this superfamily have enzymatic capacity to transfer monosaccharides from host sialyl-glycoconjugates to terminal $\beta$-galactoses of acceptor molecules located on the parasite surface, thus contributing to the parasite survival. However, this superfamily is classified in eight groups, where only groupI has enzymatic activity, and groups II-VIII are considered inactive (68). TcCRP promotes evasion of immune response, in a TS-independent manner (69-71). As expected, positive correlations between the virulence of $T$. cruzi strains and TcCRP expression levels (72) or mRNA levels (41) have been described. Moreover, TcCRP is immunogenic and induces lytic antibodies in humans and mice (32) and a DNA-based immunization confers protection against $T$. cruzi infection in mice (33). The levels of lytic antibodies induced by TcCRP in mice infected with different $T$. cruzi strains suggested that higher levels of parasitemia resulted in an increased exposition of TcCRP and other proteins, which bind to lytic antibodies present in the host's blood (34). Thus, humoral immune responses, including lytic antibody secretion, could play a role in the later replication cycle, promoting phagocytosis and cellular cytotoxicity to control the infection (34). Additionally, TcCRP is phylogenetically similar to FL-160, a TS-like protein located in the T. cruzi flagellum and flagellar pocket, with still unexplored functions (73). FL-160 derived peptides, presented by the MHC class I pathway (74) (recognized by CD8+ T cells), may have a pathogenic or protective role in chronic Chagas disease (75).

Trypomastigote glycoprotein 58/68 (gp 58/68) (58 or $68 \mathrm{kDa}$, under non-reducing or reducing conditions, respectively) (35) also inhibits C. In cell-bound and fluid-phase conditions, the protein is shown to have a dose-dependent decay-accelerating activity on the AP C3 convertase formation. However, it does not enhance the decay-dissociation of preformed AP C3 convertases and does not serve as a co-factor for Factor I (FI). Therefore, its inhibitory effect may depend on its interaction with Factor B rather than with $\mathrm{C} 3 \mathrm{~b}$ (16).

\section{OTHER MOLECULES AND MECHANISMS RELATED TO T. CRUZI C EVASION}

Factor $\mathrm{H}(\mathrm{FH})$, a $155 \mathrm{kDa}$ fluid-phase $\mathrm{C}$ negative regulatory protein, composed of 20 short consensus repeats (SCR) $(76,77)$, can accelerate the decay of the surface-bound AP C3 and C5convertases (78). In T. cruzi, FH binds with higher affinity to C3b bound to metacyclic trypomastigotes than to epimastigotes (36). FH uses 3 specific sites $(79,80)$ to interact with unique domains on C3b (79, 81-83), participates as a cofactor for Factor I (FI) and interacts with sialic acid and other related molecules $(78,84$, 85). This property is important for T. cruzi, because the parasite has TS to transfer the polyanion $\alpha(2,3)$-linked sialic acid from serum glycoconjugates to acceptor sites on the parasite surface $(86,87)$. These glycoconjugates contribute to regulate $\mathrm{C}$ activation on the parasite surface, thus behaving as a virulence factor (88-91). As sialylated molecules downregulate AP activation $(92,93)$, these polyanions transferred by TS on the trypomastigote surface may also be critical for survival in the circulation $(94,95)$. This is supported by other studies that highlight the relationship between $\mathrm{FH}$ and sialic acid to control C activity in parasites such as Toxoplasma gondii (96), Plasmodium falciparum (97-99) and Echinococcus granulosus cysts (100). Moreover, a positive correlation has been described between FH plasma level and inflammation, cardiac involvement and cardiometabolic parameters in chronic Chagas disease (101).

Extracellular vesicles (EVs) are described in several infectious- and non-infectious diseases and stress (102-107). Bloodstream and endothelial cells release EVs from their cellular membranes (107-110). EVs participate in intercellular communication, transferring glycoproteins, lipids, nucleic acids, and other biomolecular cargos. EVs may play an important role in the parasite-host cell dynamics and in the physiopathology of Chagas disease (111). T. cruzi trypomastigotes are exposed to host cell EVs and also induce EVs release from blood cells in a $\mathrm{Ca}^{2+}$-dependent manner. These vesicles bind to C3 convertase, inhibiting the catalytic activity of both the CP and LP (37). On the other hand, EVs with a TGF- $\beta$ cargo promote host cell invasion via the lysosome-independent route. This phenomenon is dose- and parasite- infective stage dependent and non-specific for parasite strains or host cell types (37). In agreement with this, higher levels of TGF- $\beta$ are found circulating in chronically infected patients (112). Thus, TGF- $\beta$-bearing EVs could activate the TGF- $\beta$ signaling pathway to promote parasite infectivity (37). Simultaneously, T. cruzi produces exosomes that stimulate different host cells to produce EVs and modulate the immune response $(37,113)$. EVs contribute to C-resistance and infectivity in trypomastigotes (114), but this response is strain-dependent since EVs derived from a more C-resistant strain can affect infectivity rate of another more susceptible T. cruzi strain (115). On the other hand, infected mice in the presence of $T$. cruzi-derived EVs present higher parasitemia $(37,116)$, and mice pre-inoculated with EVs, before infection, register higher mortality or severe pathology (117). The composition of EVs has been evaluated by proteomic and transcriptomic analysis. However, the size, amount and composition may vary according to strain, origin and life cycle stage, among others. Thus, EVs contain proteins related with metabolism, signaling, and virulence, some of them related with C evasion, such as TcCalr $(115,117-119)$.

\section{FUTURE THERAPEUTIC PERSPECTIVE}

Efforts to control Chagas disease have been mainly focused on programs aimed at the triatomine vectors. However, there is an urgent need to design new therapeutic and/or preventive tools since current treatments are not completely efficient and are seriously complicated by deleterious side effects (120). 
Cregulatory proteins released by $T$. cruzi may represent therapeutic or immunogenic/antigenic targets. Given the importance of the $\mathrm{C}$ role in innate and adaptive immune response and that T. cruzi adopts various strategies to evade $\mathrm{C}$, it is unfortunate that majority of $T$. cruzi $\mathrm{C}$ regulatory proteins have not been considered in vaccine designs or therapeutic strategies (120). Some advantages of considering C regulatory proteins expressed by $T$. cruzi as immunogens in vaccines are: 1) They intervene at different levels of the $C$ cascade and several C routes, simultaneously; 2) Some of them participate in other mechanisms involved in the host-parasite interaction, such as infectivity; 3) Most of them are highly immunogenic and, 4) Despite sharing functions with host C regulatory proteins, they are not completely homologous to their human counterparts. However, since some of these proteins share mechanisms of action, inactivation of one molecule may cause inhibition at different levels or pathways of $\mathrm{C}$ activation. Therefore, the site of action of candidate molecules must be carefully experimentally dissected out. Another unexplored possibility is to consider targeting the interaction of $\mathrm{C}$ regulatory proteins that is being hijacked by T. cruzi. The specific inhibition of catalytic sites of proteins with enzymatic roles can be ascertained. This inhibition

\section{REFERENCES}

1. Fernandes HJ, Barbosa LO, Machado TS, Campos JP, Moura AS. Meningoencephalitis Caused by Reactivation of Chagas Disease in Patient Without Known Immunosuppression. Am J Trop Med Hyg (2017) 96 (2):292-4. doi: 10.4269/ajtmh.16-0225

2. Angheben A, Boix L, Buonfrate D, Gobbi F, Bisoffi Z, Pupella S, et al. Chagas Disease and Transfusion Medicine: A Perspective From Non-Endemic Countries. Blood Transfus (2015) 13(4):540-50. doi: 10.2450/2015.0040-15

3. Maguire BJ, Dahal P, Rashan S, Ngu R, Boon A, Forsyth C, et al. The Chagas Disease Study Landscape: A Systematic Review of Clinical and Observational Antiparasitic Treatment Studies to Assess the Potential for Establishing an Individual Participant-Level Data Platform. PLoS Negl Trop Dis (2021) 15(8):e0009697. doi: 10.1371/journal.pntd.0009697

4. WHO. Chagas Disease (Also Known as American Trypanosomiasis). (2021). Available at: https://www.who.int/news-room/fact-sheets/detail/chagasdisease-(american-trypanosomiasis).

5. Alvedro A, Gaspe MS, Milbourn H, Macchiaverna NP, Laiño MA, Enriquez GF, et al. Trypanosoma cruzi Infection in Triatoma Infestans and High Levels of Human-Vector Contact Across a Rural-to-Urban Gradient in the Argentine Chaco. Parasit Vectors (2021) 14(1):35. doi: 10.1186/s13071-020-04534-z

6. Fabrizio MC, Schweigmann NJ, Bartoloni NJ. Modelling Inter-Human Transmission Dynamics of Chagas Disease: Analysis and Application. Parasitology (2014) 141(6):837-48. doi: 10.1017/s0031182013002199

7. Ingber A, Garcia MN, Leon J, Murray KO. Chagas Disease Knowledge and Risk Behaviors of the Homeless Population in Houston, TX. J Racial Ethn Health Dispar (2018) 5(2):229-34. doi: 10.1007/s40615-017-0362-0

8. Perez CJ, Lymbery AJ, Thompson RCA. Reactivation of Chagas Disease: Implications for Global Health. Trends Parasitol (2015) 31(11):595-603. doi: 10.1016/j.pt.2015.06.006

9. Cetron MS, Basilio FP, Moraes AP, Sousa AQ, Paes JN, Kahn SJ, et al. Humoral and Cellular Immune Response of Adults From Northeastern Brazil With Chronic Trypanosoma cruzi Infection: Depressed Cellular Immune Response to T. cruzi Antigen Among Chagas' Disease Patients With Symptomatic Versus Indeterminate Infection. Am J Trop Med Hyg (1993) 49(3):370-82. doi: 10.4269/ajtmh.1993.49.370

10. Hayes MM, Kierszenbaum F. Experimental Chagas' Disease: Kinetics of Lymphocyte Responses and Immunological Control of the Transition From could be performed by antibodies, nanobodies, partially or completely humanized monoclonal antibodies or natural or synthetic competitor molecules.

\section{AUTHORS CONTRIBUTIONS}

GR-T, VF, and AF contributed equally to the generation of this review. GR-T prepared the figure. GR-T, VF, and AF edited the text. LA-G, CV, and SM contributed substantially to the writing, researching previous published works, revision and approved the submitted version. All authors contributed to the article and approved the submitted version.

\section{FUNDING}

The University of Toledo Biomedical Research Innovation Program (VF), Toledo, Ohio, USA; VID, University of Chile (AF); FONDECYT-Chile 1130099 (AF), CONICYT-REDES 170126 and FIV-FAVET 12101701-9102-181 (GR-T).

Acute to Chronic Trypanosoma cruzi Infection. Infect Immun (1981) 31 (3):1117-24. doi: 10.1128/iai.31.3.1117-1124.1981

11. Zuñiga E, Motran C, Montes CL, Diaz FL, Bocco JL, Gruppi A. Trypanosoma cruzi-Induced Immunosuppression: B Cells Undergo Spontaneous Apoptosis and Lipopolysaccharide (LPS) Arrests Their Proliferation During Acute Infection. Clin Exp Immunol (2000) 119 (3):507-15. doi: 10.1046/j.1365-2249.2000.01150.x

12. Ortega Zamora Y, Escamilla Rojas LJ, Villa Sandoval EM, Vela Porras JS, Cossio Contrera EY, Cubides Romero SS, et al. Chagas Disease Immunogenetics: Elusive Markers of Disease Progression. Expert Rev Cardiovasc Ther (2017) 15 (5):367-76. doi: 10.1080/14779072.2017.1317591

13. Muniz J, Borriello A. Study on the Liturgical Action of Different Places on the Culture and Blood Forms of Schizotrypanum cruzi. Rev Bras Biol (1945) 5:563-76.

14. Rubio M. Lytic Effect of Normal Sera on Cultured and Sanguineous Forms of Trypanosoma cruzi. Bol Chil Parasitol (1956) 11(4):62-9.

15. Cestari I, Ramirez MI. Inefficient Complement System Clearance of Trypanosoma cruzi Metacyclic Trypomastigotes Enables Resistant Strains to Invade Eukaryotic Cells. PLoS One (2010) 5(3):e9721. doi: 10.1371/ journal.pone.0009721

16. Fischer E, Ouaissi MA, Velge P, Cornette J, Kazatchkine MD. Gp 58/68, a Parasite Component That Contributes to the Escape of the Trypomastigote Form of T. cruzi From Damage by the Human Alternative Complement Pathway. Immunology (1988) 65(2):299-303.

17. Norris KA, Bradt B, Cooper NR, So M. Characterization of a Trypanosoma cruzi C3 Binding Protein With Functional and Genetic Similarities to the Human Complement Regulatory Protein, Decay-Accelerating Factor. J Immunol (Baltimore Md 1950) (1991) 147(7):2240-7.

18. Norris KA, Schrimpf JE. Biochemical Analysis of the Membrane and Soluble Forms of the Complement Regulatory Protein of Trypanosoma cruzi. Infect Immun (1994) 62(1):236-43. doi: 10.1128/iai.62.1.236-243.1994

19. Beucher M, Meira WS, Zegarra V, Galvao LM, Chiari E, Norris KA. Expression and Purification of Functional, Recombinant Trypanosoma cruzi Complement Regulatory Protein. Protein Expr Purif (2003) 27 (1):19-26. doi: 10.1016/s1046-5928(02)00562-4

20. Kipnis TL, Joiner KA, da Silva WD, Rimoldi MT, Hammer CH, Sher A. Identification of Membrane Components of Trypanosoma cruzi Modulators of Complement System. Memorias do Inst Oswaldo Cruz (1988) 83(Suppl 1):571-5. doi: 10.1590/S0074-02761988000500069 
21. Tambourgi DV, Kipnis TL, da Silva WD, Joiner KA, Sher A, Heath S, et al. A Partial cDNA Clone of Trypomastigote Decay-Accelerating Factor (T-DAF), a Developmentally Regulated Complement Inhibitor of Trypanosoma cruzi, has Genetic and Functional Similarities to the Human Complement Inhibitor DAF. Infect Immun (1993) 61(9):3656-63. doi: 10.1128/ iai.61.9.3656-3663.1993

22. Ferreira V, Valck C, Sanchez G, Gingras A, Tzima S, Molina MC, et al. The Classical Activation Pathway of the Human Complement System Is Specifically Inhibited by Calreticulin From Trypanosoma cruzi. J Immunol (Baltimore Md 1950) (2004) 172(5):3042-50. doi: 10.4049/jimmunol. 172.5.3042

23. Cestari Idos S, Evans-Osses I, Freitas JC, Inal JM, Ramirez MI. Complement C2 Receptor Inhibitor Trispanning Confers an Increased Ability to Resist Complement-Mediated Lysis in Trypanosoma cruzi. J Infect Dis (2008) 198 (9):1276-83. doi: 10.1086/592167

24. Cestari Idos S, Krarup A, Sim RB, Inal JM, Ramirez MI. Role of Early Lectin Pathway Activation in the Complement-Mediated Killing of Trypanosoma cruzi. Mol Immunol (2009) 47(2-3):426-37. doi: 10.1016/j.molimm. 2009.08.030

25. Lopez NC, Valck C, Ramirez G, Rodriguez M, Ribeiro C, Orellana J, et al. Antiangiogenic and Antitumor Effects of Trypanosoma cruzi Calreticulin. PLoS Negl Trop Dis (2010) 4(7):e730. doi: 10.1371/journal.pntd.0000730

26. Sanchez-Valdez FJ, Perez Brandan C, Ramirez G, Uncos AD, Zago MP, Cimino RO, et al. A Monoallelic Deletion of the TcCRT Gene Increases the Attenuation of a Cultured Trypanosoma cruzi Strain, Protecting Against an In Vivo Virulent Challenge. PLoS Negl Trop Dis (2014) 8(2):e2696. doi: 10.1371/journal.pntd.0002696

27. Valck C, Ramirez G, Lopez N, Ribeiro CH, Maldonado I, Sanchez G, et al. Molecular Mechanisms Involved in the Inactivation of the First Component of Human Complement by Trypanosoma cruzi Calreticulin. Mol Immunol (2010) 47(7-8):1516-21. doi: 10.1016/j.molimm.2010.01.019

28. Sosoniuk E, Vallejos G, Kenawy H, Gaboriaud C, Thielens N, Fujita T, et al. Trypanosoma cruzi Calreticulin Inhibits the Complement Lectin Pathway Activation by Direct Interaction With L-Ficolin. Mol Immunol (2014) 60 (1):80-5. doi: 10.1016/j.molimm.2014.03.014

29. Ramirez G, Valck C, Molina MC, Ribeiro CH, Lopez N, Sanchez G, et al. Trypanosoma cruzi Calreticulin: A Novel Virulence Factor That Binds Complement $\mathrm{C} 1$ on the Parasite Surface and Promotes Infectivity. Immunobiology (2011) 216(1-2):265-73. doi: 10.1016/j.imbio.2010.04.001

30. Tambourgi DV, Cavinato RA, De Abreu CM, Peres BA, Kipnis TL. Detection of Trypanosoma-Decay Accelerating Factor Antibodies in Mice and Humans Infected With Trypanosoma cruzi. Am J Trop Med Hyg (1995) 52(6):516-20. doi: 10.4269/ajtmh.1995.52.516

31. Norris KA. Stable Transfection of Trypanosoma cruzi Epimastigotes With the Trypomastigote-Specific Complement Regulatory Protein cDNA Confers Complement Resistance. Infect Immun (1998) 66(6):2460-5. doi: 10.1128/IAI.66.6.2460-2465.1998

32. Martins MS, Hudson L, Krettli AU, Cançado JR, Brener Z. Human and Mouse Sera Recognize the Same Polypeptide Associated With Immunological Resistance to Trypanosoma cruzi Infection. Clin Exp Immunol (1985) 61(2):343-50.

33. Sepulveda P, Hontebeyrie M, Liegeard P, Mascilli A, Norris KA. DNA-Based Immunization With Trypanosoma cruzi Complement Regulatory Protein Elicits Complement Lytic Antibodies and Confers Protection Against Trypanosoma cruzi Infection. Infect Immun (2000) 68(9):4986-91. doi: 10.1128/iai.68.9.4986-4991.2000

34. Marques T, Silva GC, Henrique Paiva PM, Nascentes GAN, Ramirez LE, Norris K, et al. Use of Tc-rCRP as a Target for Lytic Antibody Titration After Experimental Trypanosoma cruzi Infection. Exp Parasitol (2018) 184:103-8. doi: 10.1016/j.exppara.2017.12.003

35. Velge P, Ouaissi MA, Cornette J, Afchain D, Capron A. Identification and Isolation of Trypanosoma cruzi Trypomastigote Collagen-Binding Proteins: Possible Role in Cell-Parasite Interaction. Parasitology (1988) 97( Pt 2):25568. doi: 10.1017/s0031182000058467

36. Schenkman S, Guther ML, Yoshida N. Mechanism of Resistance to Lysis by the Alternative Complement Pathway in Trypanosoma cruzi Trypomastigotes: Effect of Specific Monoclonal Antibody. I Immunol (Baltimore Md 1950) (1986) 137(5):1623-8.
37. Cestari I, Ansa-Addo E, Deolindo P, Inal JM, Ramirez MI. Trypanosoma cruzi Immune Evasion Mediated by Host Cell-Derived Microvesicles. J Immunol (Baltimore Md 1950) (2012) 188(4):1942-52. doi: 10.4049/ jimmunol.1102053

38. Inal JM, Schifferli JA. Complement C2 Receptor Inhibitor Trispanning and the Beta-Chain of C4 Share a Binding Site for Complement C2. J Immunol (Baltimore Md 1950) (2002) 168(10):5213-21. doi: 10.4049/jimmunol. 168.10 .5213

39. Inal JM. Sim RB. A Schistosoma Protein, Sh-TOR, Is a Novel Inhibitor of Complement Which Binds Human C2. FEBS Lett (2000) 470(2):131-4. doi: 10.1016/S0014-5793(00)01304-1

40. Inal JM. Complement C2 Receptor Inhibitor Trispanning: From Man to Schistosome. Springer Semin Immunopathol (2005) 27(3):320-31. doi: 10.1007/s00281-005-0009-9

41. Arroyo-Olarte RD, Martínez I, Cruz-Rivera M, Mendlovic F, Espinoza B. Complement System Contributes to Modulate the Infectivity of Susceptible TcI Strains of Trypanosoma cruzi. Memorias do Inst Oswaldo Cruz (2018) 113(4):e170332. doi: 10.1590/0074-02760170332

42. Molina MC, Ferreira V, Valck C, Aguilar L, Orellana J, Rojas A, et al. An In Vivo Role for Trypanosoma cruzi Calreticulin in Antiangiogenesis. Mol Biochem Parasitol (2005) 140(2):133-40. doi: 10.1016/j.molbiopara. 2004.12.014

43. Toledo V, Ramirez G, Valck C, Lopez N, Ribeiro CH, Maldonado I, et al. Comparative In Vivo Antiangiogenic Effects of Calreticulin From Trypanosoma cruzi and Homo Sapiens Sapiens. Biol Res (2010) 43 (3):287-9. doi: 10.4067/S0716-97602010000300004

44. Abello-Caceres P, Pizarro-Bauerle J, Rosas C, Maldonado I, AguilarGuzman L, Gonzalez C, et al. Does Native Trypanosoma cruzi Calreticulin Mediate Growth Inhibition of a Mammary Tumor During Infection? BMC Cancer (2016) 16(1):731. doi: 10.1186/s12885-016-2764-5

45. Kallinikova V, Matekin P, Ogloblina T, Leikina M, Kononenko A, Sokolova N, et al. Anticancer Properties of Flagellate Protozoan Trypanosoma cruzi chagas, 1909. Biol Bull Russian Acad Sci (2001) 28(3):244-55. doi: 10.1023/ A:1016636419597

46. Hauschka TS, Goodwin MB. Trypanosoma cruzi Endotoxin (KR) in the Treatment of Malignant Mouse Tumors. Science (1948) 107(2788):600-2. doi: $10.1126 /$ science.107.2788.600

47. Sanchez Valdez FJ, Perez Brandan C, Zago MP, Labriola C, Ferreira A, Basombrio MA. Trypanosoma cruzi Carrying a Monoallelic Deletion of the Calreticulin (TcCRT) Gene Are Susceptible to Complement Mediated Killing and Defective in Their Metacyclogenesis. Mol Immunol (2013) 53 (3):198-205. doi: 10.1016/j.molimm.2012.08.001

48. Weinberger K, Collazo N, Aguillón JC, Molina MC, Rosas C, Pena J, et al. Triatoma Infestans Calreticulin: Gene Cloning and Expression of a Main Domain That Interacts With the Host Complement System. Am J Trop Med Hyg (2016) 96(2):295-303. doi: 10.4269/ajtmh.16-0642

49. Souto-Padron T, Labriola CA, de Souza W. Immunocytochemical Localisation of Calreticulin in Trypanosoma cruzi. Histochem Cell Biol (2004) 122(6):563-9. doi: 10.1007/s00418-004-0724-7

50. Gonzalez A, Valck C, Sanchez G, Hartel S, Mansilla J, Ramirez G, et al. Trypanosoma cruzi Calreticulin Topographical Variations in Parasites Infecting Murine Macrophages. Am J Trop Med Hyg (2015) 92(5):887-97. doi: 10.4269/ajtmh.14-0497

51. Gardai SJ, McPhillips KA, Frasch SC, Janssen WJ, Starefeldt A, MurphyUllrich JE, et al. Cell-Surface Calreticulin Initiates Clearance of Viable or Apoptotic Cells Through Trans-Activation of LRP on the Phagocyte. Cell (2005) 123(2):321-34. doi: 10.1016/j.cell.2005.08.032

52. Malhotra R. Collectin Receptor (C1q Receptor): Structure and Function. Behring Inst Mitt (1993) 93):254-61.

53. Aguilar L, Ramírez G, Valck C, Molina MC, Rojas A, Schwaeble W, et al. F $\left(a b^{\prime}\right) 2$ Antibody Fragments Against Trypanosoma cruzi Calreticulin Inhibit Its Interaction With the First Component of Human Complement. Biol Res (2005) 38(2-3):187-95. doi: 10.4067/s0716-97602005000200008

54. Sosoniuk-Roche E, Vallejos G, Aguilar-Guzman L, Pizarro-Bauerle J, Weinberger K, Rosas C, et al. Exogenous Calreticulin, Incorporated Onto Non-Infective Trypanosoma cruzi Epimastigotes, Promotes Their Internalization Into Mammal Host Cells. Immunobiology (2017) 222 (3):529-35. doi: 10.1016/j.imbio.2016.10.020 
55. Crawford K, Kalionis B, Stevenson J, Brennecke S, Gude N. Calreticulin has Opposing Effects on the Migration of Human Trophoblast and Myometrial Endothelial Cells. Placenta (2012) 33(5):416-23. doi: 10.1016/ j.placenta.2012.02.003

56. Gu V, Wong M, Stevenson J, Crawford K, Brennecke S, Gude N. Calreticulin in Human Pregnancy and Pre-Eclampsia. Mol Hum Reprod (2008) 14 (5):309-15. doi: 10.1093/molehr/gan017

57. Houen G, Koch C. Human Placental Calreticulin: Purification, Characterization and Association With Other Proteins. Acta Chem Scand (1994) 48(11):905-11. doi: 10.3891/acta.chem.scand.48-0905

58. Castillo C, Ramirez G, Valck C, Aguilar L, Maldonado I, Rosas C, et al. The Interaction of Classical Complement Component C1 With Parasite and Host Calreticulin Mediates Trypanosoma cruzi Infection of Human Placenta. PLoS Negl Trop Dis (2013) 7(8):e2376. doi: 10.1371/journal.pntd.0002376

59. Llenas-García J, Wikman-Jorgensen P, Gil-Anguita C, Ramos-Sesma V, Torrús-Tendero D, Martínez-Goñi R, et al. Chagas Disease Screening in Pregnant Latin American Women: Adherence to a Systematic Screening Protocol in a Non-Endemic Country. PLoS Negl Trop Dis (2021) 15(3): e0009281. doi: 10.1371/journal.pntd.0009281

60. Evans-Osses I, Mojoli A, Beltrame MH, da Costa DE, DaRocha WD, Velavan TP, et al. Differential Ability to Resist to Complement Lysis and Invade Host Cells Mediated by MBL in R4 and 860 Strains of Trypanosoma cruzi. FEBS Lett (2014) 588(6):956-61. doi: 10.1016/j.febslet.2014.01.054

61. Ribeiro CH, Lynch NJ, Stover CM, Ali YM, Valck C, Noya-Leal F, et al. Deficiency in Mannose-Binding Lectin-Associated Serine Protease-2 Does Not Increase Susceptibility to Trypanosoma cruzi Infection. Am J Trop Med Hyg (2015) 92(2):320-4. doi: 10.4269/ajtmh.14-0236

62. Luz PR, Boldt ABW, Grisbach C, Kun JFJ, Velavan TP, Messias-Reason IJT. Association of L-Ficolin Levels and FCN2 Genotypes With Chronic Chagas Disease. PLoS One (2013) 8(4):e60237. doi: 10.1371/journal.pone.0060237

63. Peña Álvarez J, Teneb J, Maldonado I, Weinberger K, Rosas C, Lemus D, et al. Structural Bases That Underline Trypanosoma cruzi Calreticulin Proinfective, Antiangiogenic and Antitumor Properties. Immunobiology (2020) 225(1):151863. doi: 10.1016/j.imbio.2019.10.012

64. Moreau C, Cioci G, Iannello M, Laffly E, Chouquet A, Ferreira A, et al. Structures of Parasite Calreticulins Provide Insights Into Their Flexibility and Dual Carbohydrate/Peptide-Binding Properties. IUCrJ (2016) $3(\mathrm{Pt}$ 6):408-19. doi: 10.1107/s2052252516012847

65. Fujita T, Inoue T, Ogawa K, Iida K, Tamura N. The Mechanism of Action of Decay-Accelerating Factor (DAF). DAF Inhibits the Assembly of C3 Convertases by Dissociating C2a and Bb. J Exp Med (1987) 166(5):1221-8. doi: $10.1084 /$ jem.166.5.1221

66. Tambourgi DV, Kipnis TL, Dias da Silva W. Trypanosoma cruzi: AntibodyDependent Killing of Bloodstream Trypomastigotes by Mouse Bone Marrow-Derived Mast Cells and by Mastocytoma Cells. Exp Parasitol (1989) 68(2):192-201. doi: 10.1016/0014-4894(89)90097-0

67. Joiner KA, daSilva WD, Rimoldi MT, Hammer CH, Sher A, Kipnis TL. Biochemical Characterization of a Factor Produced by Trypomastigotes of Trypanosoma cruzi That Accelerates the Decay of Complement C3 Convertases. J Biol Chem (1988) 263(23):11327-35. doi: 10.1016/S00219258(18)37962-6

68. Freitas LM, Dos Santos SL, Rodrigues-Luiz GF, Mendes TA, Rodrigues TS, Gazzinelli RT, et al. Genomic Analyses, Gene Expression and Antigenic Profile of the Trans-Sialidase Superfamily of Trypanosoma cruzi Reveal an Undetected Level of Complexity. PLoS One (2011) 6(10):e25914. doi: 10.1371/journal.pone.0025914

69. Previato JO, Andrade AF, Pessolani MC, Mendonca-Previato L. Incorporation of Sialic Acid Into Trypanosoma cruzi Macromolecules. A Proposal for a New Metabolic Route. Mol Biochem Parasitol (1985) 16 (1):85-96. doi: 10.1016/0166-6851(85)90051-9

70. Freire-de-Lima L, Fonseca L, Oeltmann T, Mendonça-Previato L, Previato J. The Trans-Sialidase, the Major Trypanosoma cruzi Virulence Factor: Three Decades of Studies. Glycobiology (2015) 25(11):1142-9. doi: 10.1093/glycob/cwv057

71. Beucher M, Norris KA. Sequence Diversity of the Trypanosoma cruzi Complement Regulatory Protein Family. Infect Immun (2008) 76(2):7508. doi: 10.1128/iai.01104-07

72. Henrique PM, Marques T, da Silva MV, Nascentes GA, de Oliveira CF, Rodrigues V, et al. Correlation Between the Virulence of T. cruzi Strains,
Complement Regulatory Protein Expression Levels, and the Ability to Elicit Lytic Antibody Production. Exp Parasitol (2016) 170:66-72. doi: 10.1016/ j.exppara.2016.09.001

73. Mathieu-Daudé F, Lafay B, Touzet O, Lelièvre J, Parrado F, Bosseno MF, et al. Exploring the FL-160-CRP Gene Family Through Sequence Variability of the Complement Regulatory Protein (CRP) Expressed by the Trypomastigote Stage of Trypanosoma cruzi. Infect Genet Evol (2008) 8 (3):258-66. doi: 10.1016/j.meegid.2007.12.010

74. Garg N, Nunes MP, Tarleton RL. Delivery by Trypanosoma cruzi of Proteins Into the MHC Class I Antigen Processing and Presentation Pathway. J Immunol (Baltimore Md 1950) (1997) 158(7):3293-302.

75. Fonseca SG, Moins-Teisserenc H, Clave E, Ianni B, Nunes VL, Mady C, et al. Identification of Multiple HLA-A*0201-Restricted cruzipain and FL-160 CD8+ Epitopes Recognized by $\mathrm{T}$ Cells From Chronically Trypanosoma cruzi-Infected Patients. Microbes Infect (2005) 7(4):688-97. doi: 10.1016/ j.micinf.2005.01.001

76. Kristensen T, Tack BF. Murine Protein H Is Comprised of 20 Repeating Units, 61 Amino Acids in Length. Proc Natl Acad Sci USA (1986) 83 (11):3963-7. doi: 10.1073/pnas.83.11.3963

77. Ripoche J, Day AJ, Harris TJ, Sim RB. The Complete Amino Acid Sequence of Human Complement Factor H. Biochem J (1988) 249(2):593-602. doi: $10.1042 / b j 2490593$

78. Pangburn MK. Host Recognition and Target Differentiation by Factor $\mathrm{H}$, a Regulator of the Alternative Pathway of Complement. Immunopharmacology (2000) 49(1-2):149-57. doi: 10.1016/s0162-3109(00)80300-8

79. Sharma AK, Pangburn MK. Identification of Three Physically and Functionally Distinct Binding Sites for C3b in Human Complement Factor H by Deletion Mutagenesis. Proc Natl Acad Sci USA (1996) 93 (20):10996-1001. doi: 10.1073/pnas.93.20.10996

80. Haque A, Cortes C, Alam MN, Sreedhar M, Ferreira VP, Pangburn MK. Characterization of Binding Properties of Individual Functional Sites of Human Complement Factor H. Front Immunol (2020) 11:1728. doi: 10.3389/fimmu.2020.01728

81. Alsenz J, Schulz TF, Lambris JD, Sim RB, Dierich MP. Structural and Functional Analysis of the Complement Component Factor H With the Use of Different Enzymes and Monoclonal Antibodies to Factor H. Biochem J (1985) 232(3):841-50. doi: 10.1042/bj2320841

82. Jokiranta TS, Hellwage J, Koistinen V, Zipfel PF, Meri S. Each of the Three Binding Sites on Complement Factor H Interacts With a Distinct Site on C3b. J Biol Chem (2000) 275(36):27657-62. doi: 10.1074/jbc.M002903200

83. Lambris JD, Avila D, Becherer JD, Muller-Eberhard HJ. A Discontinuous Factor H Binding Site in the Third Component of Complement as Delineated by Synthetic Peptides. J Biol Chem (1988) 263(24):12147-50. doi: 10.1016/S0021-9258(18)37905-5

84. Alsenz J, Lambris JD, Schulz TF, Dierich MP. Localization of the Complement-Component-C3b-Binding Site and the Cofactor Activity for Factor I in the 38kda Tryptic Fragment of Factor H. Biochem J (1984) 224 (2):389-98. doi: 10.1042/bj2240389

85. Kuhn S, Skerka C, Zipfel PF. Mapping of the Complement Regulatory Domains in the Human Factor H-Like Protein 1 and in Factor H1. J Immunol (Baltimore Md 1950) (1995) 155(12):5663-70.

86. Schenkman S, Jiang MS, Hart GW, Nussenzweig V. A Novel Cell Surface Trans-Sialidase of Trypanosoma cruzi Generates a Stage-Specific Epitope Required for Invasion of Mammalian Cells. Cell (1991) 65(7):1117-25. doi: 10.1016/0092-8674(91)90008-m

87. Tomlinson S, Pontes de Carvalho LC, Vandekerckhove F, Nussenzweig V. Role of Sialic Acid in the Resistance of Trypanosoma cruzi Trypomastigotes to Complement. J Immunol (Baltimore Md 1950) (1994) 153(7):3141-7.

88. Edwards MS, Kasper DL, Jennings HJ, Baker CJ, Nicholson-Weller A. Capsular Sialic Acid Prevents Activation of the Alternative Complement Pathway by Type III, Group B Streptococci. J Immunol (Baltimore Md 1950) (1982) 128(3):1278-83.

89. Edwards MS, Wessels MR, Baker CJ. Capsular Polysaccharide Regulates Neutrophil Complement Receptor Interactions With Type III Group B Streptococci. Infect Immun (1993) 61(7):2866-71. doi: 10.1128/iai.61.7.28662871.1993

90. Marques MB, Kasper DL, Pangburn MK, Wessels MR. Prevention of C3 Deposition by Capsular Polysaccharide Is a Virulence Mechanism of Type 
III Group B Streptococci. Infect Immun (1992) 60(10):3986-93. doi: 10.1128/ iai.60.10.3986-3993.1992

91. Wetzler LM, Barry K, Blake MS, Gotschlich EC. Gonococcal Lipooligosaccharide Sialylation Prevents Complement-Dependent Killing by Immune Sera. Infect Immun (1992) 60(1):39-43. doi: 10.1128/iai.60.1.3943.1992

92. Pangburn MK, Ferreira VP, Cortes C. Discrimination Between Host and Pathogens by the Complement System. Vaccine (2008) 26(Suppl 8):I15-21. doi: 10.1016/j.vaccine.2008.11.023

93. Zipfel PF, Skerka C. Complement Regulators and Inhibitory Proteins. Nat Rev Immunol (2009) 9(10):729-40. doi: 10.1038/nri2620

94. Kipnis TL, David JR, Alper CA, Sher A, da Silva WD. Enzymatic Treatment Transforms Trypomastigotes of Trypanosoma cruzi Into Activators of Alternative Complement Pathway and Potentiates Their Uptake by Macrophages. Proc Natl Acad Sci USA (1981) 78(1):602-5. doi: 10.1073/ pnas.78.1.602

95. Sher A, Hieny S, Joiner K. Evasion of the Alternative Complement Pathway by Metacyclic Trypomastigotes of Trypanosoma cruzi: Dependence on the Developmentally Regulated Synthesis of Surface Protein and N-Linked Carbohydrate. J Immunol (Baltimore Md 1950) (1986) 137(9):2961-7.

96. Sikorski PM, Commodaro AG, Grigg ME. Toxoplasma gondii Recruits Factor $\mathrm{H}$ and $\mathrm{C} 4 \mathrm{~b}$-Binding Protein to Mediate Resistance to Serum Killing and Promote Parasite Persistence In Vivo. Front Immunol (2019) 10:3105. doi: 10.3389/fimmu.2019.03105

97. Rosa TF, Flammersfeld A, Ngwa CJ, Kiesow M, Fischer R, Zipfel PF, et al. The Plasmodium falciparum Blood Stages Acquire Factor H Family Proteins to Evade Destruction by Human Complement. Cell Microbiol (2016) 18 (4):573-90. doi: $10.1111 / \mathrm{cmi} .12535$

98. van Beek AE, Sarr I, Correa S, Nwakanma D, Brouwer MC, Wouters D, et al. Complement Factor H Levels Associate With Plasmodium falciparum Malaria Susceptibility and Severity. Open Forum Infect Dis (2018) 5(7): ofy166. doi: 10.1093/ofid/ofy166

99. Kennedy AT, Schmidt CQ, Thompson JK, Weiss GE, Taechalertpaisarn T, Gilson PR, et al. Recruitment of Factor H as a Novel Complement Evasion Strategy for Blood-Stage Plasmodium falciparum Infection. J Immunol (Baltimore Md 1950) (2016) 196(3):1239-48. doi: 10.4049/jimmunol.1501581

100. Díaz A, Ferreira A, Sim RB. Complement Evasion by Echinococcus granulosus: Sequestration of Host Factor $\mathrm{H}$ in the Hydatid Cyst Wall. J Immunol (Baltimore Md 1950) (1997) 158(8):3779-86.

101. Lidani KCF, Sandri TL, Andrade FA, Bavia L, Nisihara R, Messias-Reason IJ. Complement Factor $\mathrm{H}$ as a Potential Atherogenic Marker in Chronic Chagas' Disease. Parasite Immunol (2018) 40(7):e12537. doi: 10.1111/ pim. 12537

102. Al-Nedawi K, Meehan B, Micallef J, Lhotak V, May L, Guha A, et al. Intercellular Transfer of the Oncogenic Receptor EGFRvIII by Microvesicles Derived From Tumour Cells. Nat Cell Biol (2008) 10(5):619-24. doi: $10.1038 /$ ncb 1725

103. Bebawy M, Combes V, Lee E, Jaiswal R, Gong J, Bonhoure A, et al. Membrane Microparticles Mediate Transfer of P-Glycoprotein to Drug Sensitive Cancer Cells. Leukemia (2009) 23(9):1643-9. doi: 10.1038/ leu.2009.76

104. Combes V, Coltel N, Alibert M, van Eck M, Raymond C, Juhan-Vague I, et al. ABCA1 Gene Deletion Protects Against Cerebral Malaria: Potential Pathogenic Role of Microparticles in Neuropathology. Am J Pathol (2005) 166(1):295-302. doi: 10.1016/s0002-9440(10)62253-5

105. Combes V, Simon AC, Grau GE, Arnoux D, Camoin L, Sabatier F, et al. In Vitro Generation of Endothelial Microparticles and Possible Prothrombotic Activity in Patients With Lupus Anticoagulant. J Clin Invest (1999) 104 (1):93-102. doi: 10.1172/jci4985

106. Faille D, Combes V, Mitchell AJ, Fontaine A, Juhan-Vague I, Alessi MC, et al. Platelet Microparticles: A New Player in Malaria Parasite Cytoadherence to Human Brain Endothelium. FASEB J (2009) 23(10):3449-58. doi: 10.1096/ fj.09-135822

107. Ansa-Addo EA, Lange S, Stratton D, Antwi-Baffour S, Cestari I, Ramirez MI, et al. Human Plasma Membrane-Derived Vesicles Halt Proliferation and Induce Differentiation of THP-1 Acute Monocytic Leukemia Cells. J Immunol (Baltimore Md 1950) (2010) 185(9):5236-46. doi: 10.4049/ jimmunol.1001656
108. Gasser O, Hess C, Miot S, Deon C, Sanchez JC, Schifferli JA. Characterisation and Properties of Ectosomes Released by Human Polymorphonuclear Neutrophils. Exp Cell Res (2003) 285(2):243-57. doi: 10.1016/S0014-4827 (03)00055-7

109. Pilzer D, Gasser O, Moskovich O, Schifferli JA, Fishelson Z. Emission of Membrane Vesicles: Roles in Complement Resistance, Immunity and Cancer. Springer Semin Immunopathol (2005) 27(3):375-87. doi: 10.1007/ s00281-005-0004-1

110. Coltel N, Combes V, Wassmer SC, Chimini G, Grau GE. Cell Vesiculation and Immunopathology: Implications in Cerebral Malaria. Microbes Infect (2006) 8(8):2305-16. doi: 10.1016/j.micinf.2006.04.006

111. Rossi IV, Gavinho B, Ramirez MI. Isolation and Characterization of Extracellular Vesicles Derived From Trypanosoma cruzi. Methods Mol Biol (2019) 1955:89-104. doi: 10.1007/978-1-4939-9148-8_7

112. Araújo-Jorge TC, Waghabi MC, Hasslocher-Moreno AM, Xavier SS, Higuchi $M$, Keramidas $M$, et al. Implication of Transforming Growth Factor- $\beta 1$ in Chagas Disease Myocardiopathy. J Infect Dis (2002) 186(12):1823-8. doi: $10.1086 / 345882$

113. Mantel PY, Marti M. The Role of Extracellular Vesicles in Plasmodium and Other Protozoan Parasites. Cell Microbiol (2014) 16(3):344-54. doi: 10.1111/ cmi.12259

114. Wyllie MP, Ramirez MI. Microvesicles Released During the Interaction Between Trypanosoma cruzi TcI and TcII Strains and Host Blood Cells Inhibit Complement System and Increase the Infectivity of Metacyclic Forms of Host Cells in a Strain-Independent Process. Pathog Dis (2017) 75(7). doi: 10.1093/femspd/ftx077

115. Ribeiro KS, Vasconcellos CI, Soares RP, Mendes MT, Ellis CC, AguileraFlores M, et al. Proteomic Analysis Reveals Different Composition of Extracellular Vesicles Released by Two Trypanosoma cruzi Strains Associated With Their Distinct Interaction With Host Cells. J Extracell Vesicles (2018) 7(1):1463779. doi: 10.1080/20013078.2018.1463779

116. Ramirez MI, Deolindo P, de Messias-Reason IJ, Arigi EA, Choi H, Almeida IC, et al. Dynamic Flux of Microvesicles Modulate Parasite-Host Cell Interaction of Trypanosoma cruzi in Eukaryotic Cells. Cell Microbiol (2017) 19(4). doi: 10.1111/cmi.12672

117. Trocoli Torrecilhas AC, Tonelli RR, Pavanelli WR, da Silva JS, Schumacher RI, de Souza W, et al. Trypanosoma cruzi: Parasite Shed Vesicles Increase Heart Parasitism and Generate an Intense Inflammatory Response. Microbes Infect (2009) 11(1):29-39. doi: 10.1016/j.micinf.2008.10.003

118. Bayer-Santos E, Aguilar-Bonavides C, Rodrigues SP, Cordero EM, Marques AF, Varela-Ramirez A, et al. Proteomic Analysis of Trypanosoma cruzi Secretome: Characterization of Two Populations of Extracellular Vesicles and Soluble Proteins. J Proteome Res (2013) 12(2):883-97. doi: 10.1021/pr300947g

119. Gaur P, Chaturvedi A. Mining SNPs in Extracellular Vesicular Transcriptome of Trypanosoma cruzi: A Step Closer to Early Diagnosis of Neglected Chagas Disease. PeerJ (2016) 4:e2693. doi: 10.7717/peerj.2693

120. Dumonteil E, Bottazzi ME, Zhan B, Heffernan MJ, Jones K, Valenzuela JG, et al. Accelerating the Development of a Therapeutic Vaccine for Human Chagas Disease: Rationale and Prospects. Expert Rev Vaccines (2012) 11 (9):1043-55. doi: 10.1586/erv.12.85

Conflict of Interest: The authors declare that the research was conducted in the absence of any commercial or financial relationships that could be construed as a potential conflict of interest.

Publisher's Note: All claims expressed in this article are solely those of the authors and do not necessarily represent those of their affiliated organizations, or those of the publisher, the editors and the reviewers. Any product that may be evaluated in this article, or claim that may be made by its manufacturer, is not guaranteed or endorsed by the publisher.

Copyright $\odot 2021$ Ramírez-Toloza, Aguilar-Guzmán, Valck, Menon, Ferreira and Ferreira. This is an open-access article distributed under the terms of the Creative Commons Attribution License (CC BY). The use, distribution or reproduction in other forums is permitted, provided the original author(s) and the copyright owner(s) are credited and that the original publication in this journal is cited, in accordance with accepted academic practice. No use, distribution or reproduction is permitted which does not comply with these terms. 